\title{
Las joyas emblemáticas de Alfonso el Magnánimo*
}

\author{
Joan Domenge i Mesquida \\ Universitat de Barcelona \\ Departament d'Història de l'Art \\ domenge@ub.edu
}

\begin{abstract}
RESUMEN
Uno de los ámbitos más creativos y originales de la orfebrería gótica fue sin duda el de la joyería emblemática. La singularidad de las divisas escogidas por los príncipes más selectos exigiría a los heraldos imaginativas soluciones y a los orfebres gran pericia técnica para materializarlas. Al igual que otros soberanos de su época, Alfonso el Magnánimo (1396-1458) sucumbió de lleno en las modas emblemáticas y quiso lucir sus divisas en forma de sofisticadas joyas (collares y broches) para el engalanamiento personal. El siti perillós -o trono ardiente-, el libro abierto, el manojo de mijo y el nudo, son sus propios distintivos que manda representar por doquier y que se suman a los emblemas de la jarra y el grifo, identificativos de la orden caballeresca fundada por su padre Fernando de Antequera. Habiéndose perdido las obras, abundantes testimonios documentales y figurativos permiten evocar el aspecto y la riqueza de unas joyas que no fueron anodinos ornamentos, sino exquisitos objetos cargados de significación que connotaron profundamente la estética cortesana en el otoño de la Edad Media.
\end{abstract}

Palabras clave: Artes suntuarias, orfebrería, joyería, arte gótico, órdenes de caballería, emblemas, divisas, Corona de Aragón, Alfonso el Magnánimo.

\section{The Emblematic Jewels of Alfonso the Magnanimous}

\begin{abstract}
Emblematic jewelry was without a doubt one of the most original aspects of Gothic metalwork. Refined princes chose unique personal devices that lead heralds of arms to come up with imaginative solutions, which at their turn demanded a high level of technical expertise from goldsmiths involved in their manufacture. Like other rulers of his time, Alfonso the Magnanimous (1396-1458) gave in to this trend and wanted to see his devices represented in sophisticated pieces of jewelry (necklaces and brooches) made for his personal adornment. Alfonso's devices -Siege Perilous (burning throne), the open book, the ear of millet and the knot- were represented everywhere next to the jar and the griffin, the emblems of the chivalric order that his father, Fernando de Antequera, had founded. While the objects themselves disappeared long ago, images and documents still allow for the evocation of those extraordinary pieces
\end{abstract}

\footnotetext{
* Esta aportación se ha realizado en el marco del proyecto de investigación La corona de Aragón y las cortes septentrionales: contactos artísticos en época gótica (Ministerio de Economía y Competitividad, HAR2010-18498) que se lleva a cabo en el Departament d'Història de l'Art de la Universitat de Barcelona.
} 
of jewellery: they clearly indicate that they had not been conceived as anodyne but as intentionally exquisite products loaded with rich meaning, and they embodied the courtly aesthetics during the waning years of the Middle Ages.

Key words: Sumptuary arts, metalwork, jewellery, Gothic art, chivalric orders, emblems, devices, Crown of Aragon, Alfonso the Magnanimous.

Las vicisitudes históricas, los vaivenes de la fortuna, la fundición del oro y la plata para reutilizar el material, etc. acabaron casi por completo con la joyería de períodos tan lejanos como el Gótico. Los testimonios escritos e iconográficos permiten, hasta cierto punto, paliar tan lamentables pérdidas. Pagos de la tesorería real, inventarios, documentos notariales con listas de joyas pignoradas, etc. ofrecen detalladas descripciones que, leídas a la luz de las imágenes de los retablos, manuscritos y tapices, descubren la cara más amable de una sociedad aristocrática que se distingue por sus singulares atavíos. Paños ricos, extravagantes tocados y sofisticadas joyas son atuendos con los que se marcan diferencias, se ostenta el poder y se exhibe la supremacía.

Entre la variedad de jocalia para el engalanamiento personal (collares, broches, chapeletes, guirnaldas, cadenas, cinturones...) las alhajas emblemáticas constituyen una categoría especial, al incorporar singulares elementos cargados de significados e intenciones no siempre fáciles de descifrar. Guiados por reyes de armas y heraldos al servicio de los príncipes, los orfebres crearon, con selectos materiales, pericia técnica y abundancia de piedras preciosas, joyas y otros objetos suntuarios en los que se exhibían insólitas divisas. Con estos signos de reconocimiento e identificación, los poderosos proclamaban, en clave simbólica, intenciones políticas, sentimientos caballerescos, convicciones religiosas y ambiciones de todo tipo. La vaina de retama de Carlos VI de Francia, el camail o puercoespín del duque de Orléans o el toisón de oro de Felipe el Bueno, duque de Borgoña, son tres ejemplos representativos de la originalidad, variedad y complejidad emblemática que despunta en el atardecer de la Edad Media.

Muchas de las divisas materializadas en forma de alhaja surgen como distintivos de las órdenes de caballería tan propias de ese "Otoño de la Edad Media" que Huizinga colorea magistralmente en su obra ${ }^{1}$. No se trata ya de una caballería militar, sino más bien deportiva y decorativa, con fines altruistas y asociativos, que se regodea en los oropeles de rituales y fastos sin precedentes, de los que se hacen eco la literatura y las artes figurativas. Quienes forman parte de una orden tienen que manifestarlo luciendo opulentos collares u otros distintivos que muestran el prestigio de pertenecer a tan elitistas sociedades y revelan una tupida red curial de fidelidades. L'efflorescence emblématique es tan intensa hacia 1400 que los príncipes multiplican sus divisas -al margen de órdenes caballerescas- decorando con ellas todo tipo de objetos y contri-

1 Para una visión general sobre las órdenes de caballería de finales de la Edad Media, véase J.D.D'A. BOULTON, The Knights of the crown: the monarchical orders of knighthood in later medieval Europe, 13251520, Nueva York, 2000 (1987). 
buyendo a crear una auténtica estética que connota y distingue de modo particular el universo cortesano ${ }^{2}$.

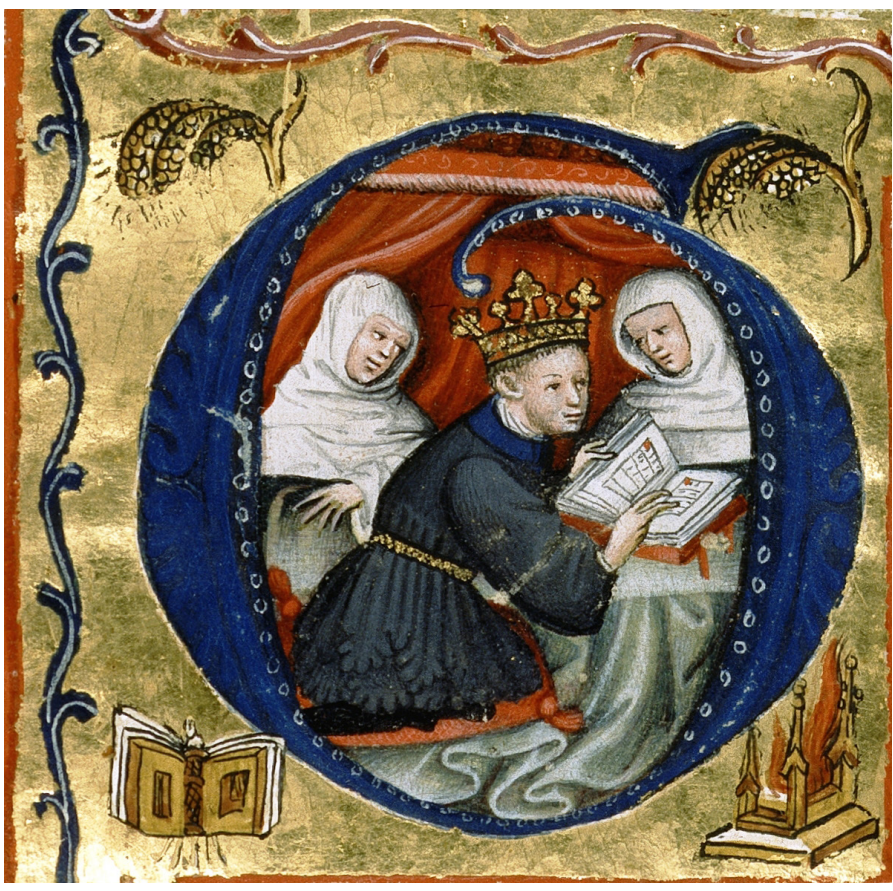

Fig. 1. Inicial con Alfonso el Magnánimo, rodeada por las divisas reales: el mijo (repetida en la parte superior), el libro abierto (ángulo inferior izquierdo) y el trono ardiente (ángulo inferior derecho). Breviario del rey Martín el Humano, París, BnF, Ms. Rotshchild 2529, fol. 444v.

A finales del s. XIV los reinos hispánicos asumen abiertamente esta moda o tendencia. Los príncipes fundan órdenes caballerescas y crean divisas que se manifiestan en múltiples esferas de su vida íntima y social. Recordemos las empresas del lebrel blanco de Carlos el Noble de Navarra, de la jarra y el grifo -fundada por el infante de Castilla Fernando de Antequera antes de subir al trono de Aragón- o de la escama, de Juan II de Castilla ${ }^{3}$. Alfonso el Magnánimo, rey de Aragón a partir de 1416, sucumbe de lleno en este fascinante mundo emblemático y durante su largo reinado (42 años) va a reunir un espectacular tesoro en el que no faltan las joyas con sus divisas: el siti

2 M. PASTOUREAU, Une histoire symbolique du Moyen Âge occidental, París, 2004; L. HABLOT, "La devise, un nouvel emblème pour les princes du XVe siècle”, E. TABURET (dir.), La création artistique en France autour de 1400, París, 2006, pp. 177-192. Sobre la incidencia del mundo emblemático en la joyería medieval, véanse los respectivos capítulos del documentado estudio de: R.W. LIGHTBOWN, Mediaeval European Jewellery, Londres, 1992.

3 M. NARBONA, "Le roi de la bonne foy. Charles III le Noble et les devises des Navarre-Évreux au XV $V^{\mathrm{e}}$ siècle”, D. TURREL et al. (eds.), Signes et couleurs des identités politiques du Moyen Âge à nos jours, Rennes, 2008, pp. 477-509; A. FERNÁNDEZ DE CÓRDOVA, "Las divisas del rey: escamas y ristres en la corte de Juan II de Castilla", Reales Sitios, 191 (2012), pp. 22-37. 
perillós (o trono ardiente), el manojo de mijo y el libro abierto (Fig. 1). Detalladas descripciones e imágenes de las divisas alfonsinas nos ayudarán a imaginar el aspecto que debieron tener estos joyeles ${ }^{4}$.

Alfonso deviene infante heredero de la corona cuando su padre Fernando de Antequera sube al trono de Aragón en 1412. Ante tan honorable destino no es de extrañar que se inicie un inventario de todas sus joyes, robes e altres coses que, a pesar de llegarnos incompleto, constituye una fuente excepcional para conocer los bienes del primogènit del senyor Rey y los vaivenes de su cámara ${ }^{5}$. A lo largo de una docena de años se anotarán entradas y salidas de objetos en este registro, permitiéndonos conocer los usos del tesoro principesco y descubrir a algunos de los "incondicionales" de Alfonso, agraciados con piezas impregnadas del aura real. Entre las joyas para el adorno personal se registran: una corona de oro -con balajes y perlas-, chapeletes, correas, cinturones de aparato, cadenas, rosarios, brazaletes, etc. realizados mayormente en oro y combinados con otros selectos materiales, perlas y pedrería. Destacan una serie de collares con originales formas de inspiración vegetal, resueltas con los esmaltes de moda: blanco, verde y rogicler. También llaman la atención varios broches sembrados de zafiros, balajes, diamantes y perlas, cuyos motivos figurativos incorporan el novedoso esmalte blanco opaco ${ }^{6}$. En algunas piezas inventariadas campea la divisa de la orden de su padre, "la jarra y el grifo", llamando la atención tres soberbios collares que más adelante trataremos.

$* * *$

El despliegue emblemático del Magnánimo debió de producirse en los años veinte, como se confirma en un elenco de alhajas que el rey deposita en la taula de canvi de Barcelona en 14297. Las tres divisas principales de Alfonso hacen su aparición

\footnotetext{
4 Para una aproximación a la personalidad del Magnánimo remitimos a la clásica monografía de A. RYDER, Alfonso el Magnánimo, rey de Aragón, Nápoles y Sicilia, 1396-1458, Valencia, 1992. Sobre el significado y localización de los emblemas alfonsinos, cfr. J. DOMENGE, "La gran sala de Castelnuovo. Memoria del Alphonsi regis triumphus", G.T. COLESANTI (a cura di), Le usate leggiadrie. I cortei, le ceremonie, le feste e il costume nel Mediterraneo tra il XV e XVI secolo, Montella, 2010, pp. 307-325. Véanse además las recientes aportaciones de: J. MOLINA, "Un trono in fiamme per il re. La metamorfosi cavalleresca di Alfonso il Magnanimo", Rassegna Storica Salernitana, XXVIII/2, 56 (2011), pp. 11-44; E. JUNCOSA BONET, "El rei Alfons i la promoció de la magnanimitat", M.R. TERÉS (coord.), Capitula facta et firmata. Inquietuds artístiques en el quatre-cents, Valls, 2011, pp. 141-166; R. BELTRÁN, "Els diàlegs matrimonials de la casa de Borgonya i els emblemes amorosos al Tirant lo Blanc", Tirant, 14 (2011), pp. 86-92.

5 E. GONZÁLEZ HURTEBISE, "Inventario de los bienes muebles de Alfonso V de Aragón como infante y como rey (1412-1424)", Anuari de l'Institut d'Estudis Catalans, 1907, pp. 148-188.

6 La magnífica colección de broches de fabricación parisina que se conservan en la catedral de Essen (c. 1390) ayuda a visualizar cómo pudieron ser los fermalls perdidos de Alfonso. Sobre la orfebrería gótica al filo del 1400, véase: Paris·1400. Les arts sous Charles VI, catálogo de la exposición, París, 2004; E. KOVÁCS, L'âge d'or de l'orfèvrerie parisienne, Dijon, 2004. Tratamos de la incidencia que pudieron tener las nuevas técnicas en la producción suntuaria hispánica en J. DOMENGE, "Circulation d'objets, d'orfèvres et de techniques: l'émail en ronde-bosse en Espagne autour de 1400", Les transferts artistiques dans l'Europe de l'époque gothique, París, 2014, pp. 141-162..

7 M. TINTÓ I SALA, "Dos fermalls i altres joies d'Alfons el Magnànim, segons un inventari de la taula de canvi de la Ciutat de Barcelona", Acta Historica et Archaeologica Medievalia, 26 (2005), pp. 767-773. Junto
} 
en deslumbrantes piezas de oro -repletas de perlas y piedras preciosas- para el engalanamiento personal del rey, que se guardaban con esmero en estuches de cuero sellados con las armas de Aragón y/o Sicilia. Este "tesoro" es representativo del valor de los encargos de Alfonso, de su inclinación al fasto y de sus inversiones exorbitantes en objetos suntuarios, aunque demasiado a menudo se viera en la necesidad de desprenderse temporalmente de ellos para disponer de recursos con los que atender necesidades vitales y ambiciosos proyectos políticos.

La primera joya emblemática descrita en 1429 es un gran collar de oro con la empresa del mijo, combinada con 18 balajes -unos irregulares, en forma de còdols, otros tallados a manera de losa- y 71 perlas "grandes, claras, redondas", especifica el escribano, seguramente para subrayar su valor y belleza. El mismo emblema se repite en un broche pequeño de oro fino, obrado a manera de una mata de mill, adornado también con pedrería y perlas. Esta divisa estaba pues en dos de las alhajas más codiciadas de la época: collares y broches. Los inventarios, las novelas de caballería y las pinturas que muestran cómo vestían las personas de rango acreditan la difusión y el prestigio de estos adornos. ¿Qué aspecto tenían los joyeles de Alfonso? Tan solo podemos imaginarlos a partir de los testimonios gráficos que del manojo de mijos nos brindan medallas, cerámicas, sellos, manuscritos... El mijo, símbolo de fecundidad y prodigalidad de la tierra, asume en el contexto alfonsí un significado mucho más directo y personal que la ficción literaria, al apropiarse de la realidad, contribuye a desvelar. En la novela Tirant lo Blanc, el protagonista viste un manto con espigas de mijo acompañadas con las letras del refrán "Uno vale mill y mill no vale uno". El rey Alfonso vale por mill y la divisa deviene un auténtico manifiesto de propaganda real al proclamar el valor, el coraje y la fuerza del Magnánimo, en definitiva sus virtudes caballerescas y su valentía en el combate.

Otro de los collares guardados en la taula de canvi estaba obrado a modo de bavera y llevaba letras esmaltadas. Su valor emblemático residía en el colgante: un libro de oro que llevaba engastados un balaje losa y un bello diamante lanzengat; tres perlas grandes y redondas colgaban de los registros del libro. La divisa del libro debía de representarse según los rasgos comunes que conocemos a partir de múltiples testimonios gráficos: un libro abierto, visto por las cubiertas, como si alguien estuviera leyéndolo y con los registros colgando en la parte inferior. El historiógrafo de corte Beccadelli-conocido como el Panormita- descubre el significado de esta divisa en su libro "De los dichos y hechos del rey Alfonso". Con ella Alfonso proclama que lleva el saber por insignia, que ama los libros y que el conocimiento de las artes y ciencias, propio de reyes, se alcanza solo leyendo, estudiando y amando los libros. Muestra así otra faceta de la personalidad del rey y reviste su imagen con un toque de intelectualidad y de cultura, incluso mucho antes de que se formara el círculo de humanistas a su alrededor en la etapa napolitana. Sea como fuere, lo cierto es que poseer bellos

a las joyas con emblemas se describen otras alhajas de gran valor, algunas piedras y perlas sueltas, así como dos piezas de orfebrería religiosa.

8 A. BECCADELLI, EL PANORMITA, Dels fets e dits del gran rey Alfonso, E. DURAN (ed.), Barcelona, 1990, p. 145. 
libros y disponer de una buena librería era entonces también un "ornamento" de las monarquías que se querían prestigiosas.



Fig. 2. Busto de Fernando I de Nápoles o de Alfonso de Aragón, duque de Calabria. Nápoles, Museo di Capodimonte, inv. AM 10527.

Una tercera joya llevaba la otra divisa que el Magnánimo utilizó asiduamente, pues entre los eslabones esmaltados de un collar, semejantes a algas de mar, se distinguían los citis perillosos (la silla peligrosa o trono ardiente). Pendía del collar un colgante de oro fino, a modo de espejo, con letras esmaltadas en blanco y rojo -quizás un mote relacionado con la divisa- y un molt bell e gros diamant. Los múltiples ejemplos de esta divisa, representados en los márgenes de los manuscritos reales y en otros contextos, ayudan a imaginar cómo podían ser los citis del collar. Su significado tampoco suscita dudas. El trono ardiente es una imagen de la literatura artúrica que alude a la silla vacía de los caballeros de la mesa redonda, reservada al victorioso Galaad tras la conquista del Santo Grial. Quien quiera ocuparla sin llevar a cabo la proeza, perecerá inflamado. Con esta divisa Alfonso quiere presentarse como un nuevo Galaad lanzado a la conquista del trono de Nápoles. Lo proclama en su discurso una de las virtudes de los entremeses que desfilaron el día en que se festejó el triunfo de Alfonso sobre Nápoles ${ }^{9}$. No acaso unos años después, al hacerse representar triunfante en el arco de ingreso al Castel Nuovo, no queda la menor duda de que él puede ocupar legítima y

9 E la una de les dites Virtuts ab alta veu significà e parlà al dit senyor: que la dita empresa del dit siti perillós, per la benaventurada conquesta havie son obtente, com algun altre rey, príncep ne senyor no ere stat digne de seure sobre aquell siti, sinó lo dit senyor que havia supeditat e obtengut lo dit reyalme. 
cómodamente este trono sin peligro de incendiarse; las llamas han quedado depuestas a sus pies.

Los collares que Alfonso tenía en 1429 no serían muy distintos de los que luce su hijo bastardo Fernando, heredero del trono de Nápoles, en dos bustos conservados en el Museo Capodimonte de Nápoles (Fig. 2). En ambos se ven atrevidas -y seguramente muy intencionadas- combinaciones de las divisas paternas con las propias: el monte de diamantes y el armiño ${ }^{10}$. Aunque en los collares de Alfonso los mijos estuvieran en los eslabones, el libro fuera un colgante, y los tronos ardientes se unieran con algas de mar, las alhajas de Fernando muestran cómo se podían combinar o asociar a otras divisas, según una lógica que, de existir, se nos escapa. Sea como fuere, el resultado son unas joyas con mensaje -para quien sepa interpretarlo, por supuesto-y no simples ornamentos carentes de significación.

$* * *$

Las divisas reales podían verse también en objetos que el soberano encargaba para sus ofrendas religiosas -contribuyendo a perpetuar el recuerdo del donante- y en los que recibía como regalos, sirviendo tanto para recordar a quien lo ofrecía como para envanecer al receptor con sus personales marcas. Sirvan tres destacados ejemplos de orfebrería para corroborarlo. En 1426 Alfonso mandaba labrar al orfebre Bernat Daries, para entregarlo a los agustinos de Valencia, un cáliz y una patena de plata dorada con tres esmaltes en el pie; en uno figuraban las armas de Aragón y Sicilia y en los dos restantes les divises del dit Senyor, dels libres e spigues de mill en campo azul ${ }^{11}$. En un memorial de las alhajas empeñadas por el rey para subvencionar sus campañas napolitanas (1431) se alistaron, entre otros muchos objetos de plata, diez imágenes de apóstoles en cuyas peanas llevaban los escudos de Aragón y Sicilia; en las esculturas de San Bartolomé, Santiago el Menor y Santo Tomás también se hallaba la divisa del libro ${ }^{12}$.

En 1451 los consellers de la ciudad de Barcelona quisieron agraciar y persuadir al monarca regalándole dos piezas excepcionales: una escultura de Santa Eulalia en oro y una conca o gran cuenco de plata. De estos objetos se conserva una abundante y detallada documentación que permite conocer todo el proceso, desde la decisión de fabricarlas hasta la recepción y reacción entusiasta por parte del insigne destinatario, pasando por el acopio del material, la ejecución, el pago de las obras y el reconoci-

J.M. MADURELL, Mensajeros barceloneses en la corte de Nápoles de Alfonso V de Aragón, 1435-1458, Barcelona, 1963, p. 218.

10 Uno, en bronce, atribuido al escultor de Módena, Guido Mazzoni, representa a Fernando, o bien a su hijo el duque de Calabria, Alfonso II. El otro, en mármol, lleva la inscripción Ferdinandus rex inclitus y en su collar, sin colgante, se alternan solamente los emblemas del siti perillós y del monte de diamantes.

11 J. SANCHIS SIVERA, La orfebrería valenciana en la Edad Media, Valencia, 1924, pp. 19-20. Publica también el documento, J.V. GARCÍA MARSILLA, "El poder visible. Demanda y funciones del arte en la corte de Alfonso el Magnánimo", Ars Longa, 7-8 (1996-1997), pp. 42-43.

12 A. DURAN I SANPERE, "Joies i obres d'art empenyorades i venudes per a la campanya de Nàpols", IDEM, Barcelona i la seva història, vol. 3: L'art i la cultura, Barcelona, 1975, p. 272. 
miento o visura de las mismas ${ }^{13}$. Puesto que se trata de una información que va más allá de lo anecdótico y nos adentra tanto en la cotidianeidad como en los valores simbólicos que revisten estos encargos, creo conveniente destacar algunos aspectos.

El propósito que mueve a los consejeros está claramente expresado: ofrecer un presente al rey Alfonso que sia bell e poxant, a imagen de la ciudad que lo ofrece, pues a través del regalo, "la fama de dicha ciudad resonará en aquellas partes", se dice literalmente. Deciden encargar una imagen de oro de santa Eulalia, patrona de la ciudad, para la capilla del rey y una bella e gran concha de plata sobredorada para el tinelo real ${ }^{14}$; se trataba de un artilugio que podía servir de bañera, pues tenía un dispositivo en el que podían insertarse las varas de un pabellón para que quant lo dit Senyor se volrà mullar, puxe entrar en bany dins la dita concha. Ambas piezas llevarían las armas reales y municipales con la intención de que "cuando el rey viera dichos joyeles tuviera en la memoria a dicha ciudad", o sea, no se olvidara de Barcelona. Alrededor del cuenco campearían además las divisas del rey ço és, los mills, libres e sitis perillosos.

Mientras el afamado platero Francesc Artau estaba inmerso en la ejecución de las piezas, un emisario barcelonés enviado a la corte de Nápoles aprovechaba la disponibilidad e interés del rey para avanzarle aspectos del obsequio que Barcelona le estaba preparando, como preámbulo - y calculada estrategia- para luego abordar temas políticos más espinosos. El mensajero describe las obras, subrayando que en el cuenco se alternan los gallones dorados y plateados y que en cada gallón se ve una de las divisas reales. Suplica al rey que excuse la tardanza, pues quieren corresponder a su dignidad con piezas magníficamente acabadas. Alfonso reacciona manifestando gran satisfacción y alabando el acierto de la alternancia cromática de los gallones, pues de ser todos dorados parecerían de latón. Ciertamente no interesaba que así fuera: el regalo era de gran valor y su apariencia no podía falsearlo. El soberano se interesa también por saber si es el orfebre Lleopart quien ejecuta las piezas, manifestando conocer a los artífices y tener claras sus preferencias ${ }^{15}$.

Las obras llegaron sanas y salvas a Nápoles el 31 de enero de 1452, lo que fue motivo de satisfacción por parte del monarca, dada la inminente celebración de la fiesta de santa Eulalia, el 12 de febrero. Los pormenores de la entrega de las piezas también se narran en la correspondencia de los mensajeros Vinyes y Desplà. Comentan no poder describir la alegría y placer de Alfonso ante los obsequios y recuerdan las alabanzas unánimes del rey y de sus curiales -magnific $i$ ben obrat $i$ que semblava que Barcelona el trametia - seguramente para complacer a los consejeros de Barcelona por un esfuerzo económico tan grande. La estatua lució en la capilla real el día de Santa Eulalia, presidiendo desde lo más alto el conjunto de imágenes y candelabros

13 La publica detalladamente: J.M. MADURELL, "El arte en la Comarca Alta de Urgel", Anales y Boletín de los Museos de Arte de Barcelona, IV, 1/2 (1946), pp. 78-79, y J.M. MADURELL, op. cit., 1963, docs. 366, 390-393 y 413.

14 Se dan también otros pormenores de las obras: el peso, las medidas y el coste, realmente exorbitante, pues ascendía a 5.500 libras.

15 A propósito de los plateros Artau y Lleopart -quien por indisposición no pudo asumir el encargo-, véase la documentación reunida por N. DE DALMASES, Orfebreria catalana medieval: Barcelona 1300-1500 (aproximació a l'estudi), vol. II, Barcelona, 1992, pp. 25-27 y 88-91. 
de plata que se exhibieron en una tarima del altar mayor. Según el testimonio de los mensajeros, el rey quedó altamente satisfecho de la visión de esta imagen -más si cabe que al recibirla - y constató que por su belleza y gallardía eclipsaba a las restantes figuras. Vinyes relata que la atracción de la imagen fue algo milagroso; todos los asistentes quedaron embelesados y nadie podía despegar su mirada de la áurea santa. La invocación final del emisario acaba por revelar la intención de los consejeros y el sentido interesado de los dos presentes: A Déu plàcie (...) vulla prest anar visitar sos regnes e terres. La información acerca de estas obras concluye con la carta de agradecimiento de Alfonso a los representantes barceloneses ${ }^{16}$. Merece la pena insistir en la valoración que se hace de la belleza y técnica de las piezas, pero también de la dignidad de las mismas, lo que contribuye a dignificar a quien recibe el regalo (el rey) y a quienes lo han ofrecido (los consejeros, en representación de la ciudad de Barcelona).

En Nápoles, Alfonso el Magnánimo utilizó una cuarta divisa, el nudo, muy representada en la arquitectura y en otras iniciativas artísticas partenopeas, especialmente en manuscritos ilustrados. Los porqués y razones de este nuevo emblema no son fáciles de esclarecer; es probable que se apropiara del distintivo de la orden del Santo Espíritu au droit désir, fundada en 1352 por Luis de Tarento, rey de Nápoles, conocida también como la orden del nudo. No obstante la forma específica de la divisa era distinta a como se la representa en el entorno alfonsi ${ }^{17}$. La presencia de este emblema en la joyería del rey parece muy limitada y aún dudosa. En 1455 la tesorería real remunera varias piezas al orfebre Guido d'Antonio, entre ellas un collar de oro de la divisa de Nuestra Señora, con 30 giarrette e 30 nodi con un grifo pendente, tutto di oro di 20 carati, che donò al suo paggio Messer Simonetto di Settimo ${ }^{18}$. Puede que los 30 nudos no tuvieran necesariamente un sentido emblemático y fueran simples eslabones de formas retorcidas que se alternaban con las giarrette.

Las jarras ciertamente eran emblemas de la orden de Santa María o de Nuestra Señora. Conocida también con el nombre de "la jarra y el grifo" -o de "la estola"- esta orden caballeresca había sido creada por el padre de Alfonso, Fernando de Antequera $^{19}$, el día de la Asunción de la Virgen de 1403, en honor a María, "su señora y abogada", como explicita en el proemio del documento fundacional de la orden ${ }^{20}$. Se aclara

16 Vos regraciam, quant més podem, la dita ymage d'or e conca d'argent, tant per ésser cascuna en sa spècie de singular perfecció e bellesa, quant encara per ésser coses dignes, axi a nos, a qui ho haveu donat e fet presentar, com a vosaltres per part de qui nos són stades presentades. J.M. MADURELL, op. cit., 1963, doc. 413.

17 J. DOMENGE, op. cit., 2010, pp. 320-322.

18 Puesto que los documentos originales no se conservan, remitimos a los extractos de C. MINIERI RICCIO, "Alcuni fatti di Alfonso I di Aragona", Archivio Storico per le Provincie Napoletane, VI (1881), p. 436.

19 Sobre el personaje, véanse las recientes monografías de: D. GARRIDO, Ferran I "el d'Antequera" un rei de convèniencia, Valencia, 2011; S. GONZÁLEZ SÁNCHEZ, Fernando I regente de Castilla y rey de Aragón (1407-1416), Gijón, 2012.

20 J. Villanueva dio a conocer una versión en catalán de los estatutos de la orden a partir de un códice del convento de Santo Domingo de Barcelona. J. VILLANUEVA, Viage literario a las iglesias de España, 
seguidamente la elección del motivo de la jarra: "E por remembrança del plazer que ella en si resçibió quando la saludó el ángel Gabriel, tomé un collar por devisa de las sus jarras de la Salutaçión". No es de extrañar que elija un collar como distintivo de la nueva orden; hacia 1400 la mayoría de sociedades curiales que se fundan optan por extravagantes collares para prestigiar y distinguir a sus miembros, dejando atrás otros ornamentos textiles y joyas menos opulentas ${ }^{21}$.

La devoción a María le llevó, pues, a escoger un motivo iconográfico mariano harto representado en la plástica de época gótica: la jarra con los lirios o azucenas, símbolo de la pureza e inocencia de María en la Anunciación y de su concepción inmaculada. El jarrón con lirios es omnipresente en las Anunciaciones pintadas, adquiriendo a menudo visos de un verdadero emblema, pues suele desmarcarse de la composición y situarse en un primer plano, separando por lo general a las figuras y asumiendo un indiscutible protagonismo visual; otras veces se integra en la escena, ubicándose en un plano más lejano, pero conservando su posición central.

Junto a este motivo religioso, el infante Fernando escogió otro emblema para connotar caballerescamente a su orden. El collar debía completarse con un colgante en forma de grifo, al que se alude en la joya napolitana antes evocada. Su significado también se desvela con claridad en los estatutos ${ }^{22}$ : el grifo es escogido por ser el más fuerte de los animales, virtud que se espera de los caballeros de la orden. En efecto, se les exige fortaleza y firmeza no solo en su amor a Dios y a la Virgen sino también en todo lo tocante a la caballería. El propio fundador de la orden al elegir este animal mitológico se hacía eco de sus valores simbólicos, asumidos por el cristianismo en los bestiarios y visiones alegóricas. Mitad león y mitad águila, el grifo reúne la fuerza del rey de los animales terrestres y de la reina de las aves.

Todavía un tercer distintivo, tal vez de uso voluntario, podía identificar a quienes pertenecían a la orden. Los sábados y fiestas de Santa María podían vestir de blanco o bien traer "una faxa blanca de tres dedos arriba en ancho" sin ornamentación alguna que no fuera blanca, como bordados y aljófar. Esta banda textil puede que al fin acabara siendo preceptiva, pues muchos caballeros de la orden se hicieron representar con ella y el nombre de "orden de la estola" con el que también se conocía a esta sociedad da fe de la importancia que tuvo este distintivo. Caballeros como Heinrich Blarer o el poeta Oswald von Wolkenstein se hicieron retratar con ella ${ }^{23}$ (Fig. 4). La

XVIII: Viage á Barcelona, Madrid, 1851, pp. 307-312. Seguiremos la versión castellana contenida en un manuscrito de la Real Biblioteca del Monasterio de San Lorenzo del Escorial (Madrid), publicada por G. VITALE, Araldica e politica. Statuti di ordini cavallereschi "curiali" nella Napoli aragonese, Salerno, 1999, pp. 103-108.

21 Lo corrobora R.W. LIGHTBOWN, op. cit., 1992, p. 260: Nevertheless collars fashioned of links shaped to figure a device or riband collars with a badge or device hanging from them were destined to become the usual insignia of a chivalric order.

22 "del qual collar viene un gryffo colgado, en significaçión que ansy como el griffo es fuerte sobre todas las otras animalias, que ansy todos los de la dicha devisa deven ser fuertes e firmes en el amor de Dios e de la Virgen sancta Maria, e esso mesmo en las obras de cavallería". Los méritos militares de los miembros de la orden, contra moros o en cualquier batalla, quedaban reflejados en este emblema, con el dorado sucesivo de las dos alas del grifo.

23 R.W. LIGHTBOWN, op. cit., 1992, pp. 272 y 449. En el retrato de Blarer aparece también el grifo en la parte superior derecha. 
lleva también el propio Fernando de Antequera en una miniatura del libro de horas de su hijo Alfonso en la que se escenifican sus exequias. Se intuye de un tejido blanquecino y semitransparente, y como en las restantes representaciones, una jarra con tres lirios decora la banda a manera de broche ${ }^{24}$.

La identificación de la orden con sus emblemas -en especial con el collar-es tan estrecha que en los estatutos, al sucederse los capítulos para señalar las obligaciones de los miembros, se hace referencia a ellos como "los de la dicha devisa". Desde la fundación de la orden, jarras y grifos son omnipresentes en el entorno curial de Fernando y continuarán siéndolo en tiempo de sus sucesores. Además de la insignia del collar, los documentos corroboran que estandartes, orfebrerías, armas, tejidos, etc. llevaban la empresa de las jarras de Santa María. Alfonso ya fue condecorado con ella a los siete años, el día de la fundación de la orden. También lo fueron su madre, su hermano Juan (el futuro rey de Aragón Juan II) y "otros ricos hombres cavalleros e gentiles hombres e señoras, dueñas e doncellas que allí estavan", algunos de los cuales son identificados. No es de extrañar, pues, que el inventario de sus bienes revele el peso específico que este emblema tuvo en la ornamentación de varios objetos personales, alguno sin duda herencia de su padre.

Entre las piezas descritas que llevan las çetras o jarras de Santa María reclaman nuestra atención tres impactantes collares de gran suntuosidad ${ }^{25}$. En uno se combinaban 9 jarras de lirios con 9 hojas de trébol, en cuyo centro había flores de borraja $\mathrm{y}$ una hoja colgando de cada flor. El pandant o colgante era un grifo blanco acompañado con un título o lema que rezaba Per vostra amor, del que no se hace mención alguna en los estatutos de la orden. Sin embargo, asociar un mote a las divisas fue práctica común en la época, y en uno de los más detallados testimonios iconográficos del collar - un retrato de emperador Federico III- constatamos que el pintor conocía el mote y pudo reproducirlo de forma aproximada ${ }^{26}$ (Fig. 6). Una interesante versión escultórica, aunque más sencilla que el ejemplar descrito, se ve en el yacente del adelantado Gómez Manrique, procedente del monasterio de Fresdelval y conservado en el Museo de Burgos ${ }^{27}$ (Fig. 3). La anotación que sigue a la descripción del collar alfonsí revela el destino que podían tener semejantes joyas, precisamente a causa de su valor emblemático. La voluntad del rey de conceder su empresa a caballeros que la merecían podía provocar la fragmentación de las piezas, si no se tenía liquidez para encargos suntuarios de este calibre; en el inventario se indica la cancelación de ocho jarras que fueron distribuidas por el rey a varios caballeros. A destacar que en estos

24 F. ESPAÑOL, Els Escenaris del rei. Art i monarquia a la Corona d'Aragó, Manresa, 2001, p. 215. Podemos imaginar el aspecto de estas jarras gracias a la que aparece en el centro de una joya en forma de M con la Anunciación, conservada en Oxford y fechada hacia 1400. J. ALEXANDER y P. BISNKI (eds.), Age of Chivalry. Art in Plantagenet England 1200-1400, catálogo de la exposición, Londres, 1987, p. 483.

25 E. GONZÁLEZ HURTEBISE, op. cit. (1907), pp. 164-166.

26 En realidad el mote que se ve en la pintura reza Per bon amor. E. KOVÁCS, op. cit., 2004, pp. 294-295. El retrato se considera una copia realizada por Hans Burgkmair el Viejo a partir de un original perdido de 1468. Cfr. Hispania-Austria. I re cattolici, Massimiliano I e gli inizi della Casa d'Austria in Spagna: arte intorno al 1492, catálogo de la exposición (Innsbruck, 1992), Milán, 1992, cat. 87, p. 259.

27 R.W. LIGHTBOWN, op. cit., 1992, pp. 261-262. Las jarras van unidas por sendas cadenas, el escultor no alcanza a reproducir de forma realista el aspecto de los lirios y sobre el pecho del yacente destaca un gran grifo con una filacteria en sus garras, en la que debiera constar el pertinente mote. 
casos no se condecoraba con un collar, sino tan solo con una jarrita que probablemente se usaría como broche ${ }^{28}$.

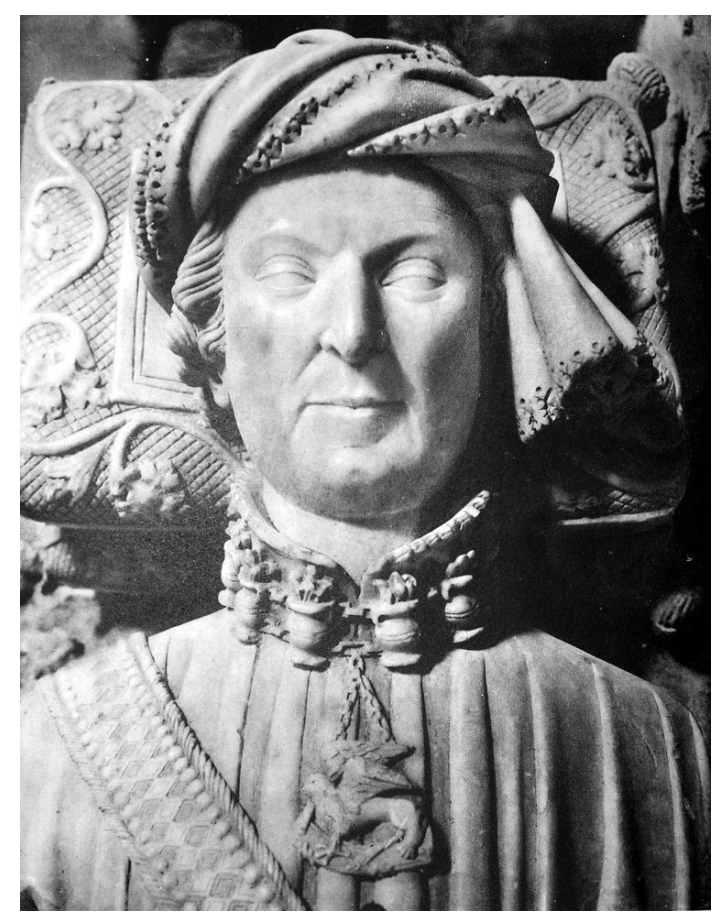

Fig. 3. Yacente del adelantado Gómez Manrique (†1411), procedente del monasterio jerónimo de Fresdelval. Museo de Burgos.

Todavía más opulento era un segundo collar, con 42 eslabones, compuesto cada uno por dos jarras en dirección opuesta, separadas por una roseta esmaltada de blanco. Un matiz cromático diferenciaba los lirios inferiores -en oro- de los superiores que, alcanzando visos de mayor realismo, llevaban esmaltes verdes y blancos, seguramente para diferenciar el tallo y las hojas de las flores ${ }^{29}$. El orfebre encargado de su fabricación utilizaría las técnicas de esmaltar el oro que hacia 1400 habían alcanzado cotas de gran refinamiento en algunos prestigiosos talleres de París. La suntuosidad de ese collar se incrementaba todavía con una hoja de oro bruñido colgando de cada eslabón, según hábitos muy arraigados en la joyería coetánea ${ }^{30}$, pero no se indica que llevara el colgante del grifo. Muy agradecido estaría el rey Alfonso a su camarero

28 Las mencionadas imágenes de Alfonso, Blarer y von Wolkenstein corroboran esta práctica.

29 Sirvan de referente las joyas con flores - esmaltadas en blanco y verde- de la catedral de Essen. E. KOVÁCS, op. cit., 2004, p. 256.

30 En las miniaturas de las Très Riches Heures del duque de Berry se ve a los cortesanos con cadenas de las que cuelgan pequeñas hojas y en los tapices de las cacerías de Devonshire (Londres, Victoria \& Albert Museum), varios personajes ostentan ricos y variados collares de hojas. 
Gonçalvo de Muntroy, o mejor dicho a su esposa, para que el 10 de octubre de 1417 mandase cancelar la alhaja para ofrecerla a esta señora.

En un tercer collar de diferente diseño aparecían de nuevo las jarras, sin el grifo. La base de los 18 eslabones era una hoja de oro, en 12 de ellas se sobreponía la divisa (la jarra), mientras en las 6 restantes se repetía un fermall de moda, en forma de flor, con un balaje central rodeado por doce perlas ${ }^{31}$; el efecto cromático debía resultar atractivo gracias al contraste de la transparencia morada de los balajes con el blanco nacarado de las perlas. Se recuerda que el collar fue un regalo que el rey Fernando hizo a su hijo al casar con María de Castilla (1415). No obstante se trataría de un obsequio que requirió la colaboración de Alfonso al tener que aportar cuatro de los seis balajes que lo enriquecían, corriendo todo lo demás a cargo de su padre. No tienen que sorprender situaciones como estas; los soberanos podían verse en la necesidad de empeñar, si no joyas enteras, al menos valiosas piedras de las mismas. Seguramente las nupcias de Alfonso cogieron al rey desprevenido, falto en este caso de algunos de los balajes que se necesitaban para completar el collar que quería ofrecer al primogénito en tan señalada ocasión.

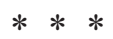

La descripción detallada de la forma, materiales y ornamentos de estos collares que se da en el inventario de Alfonso puede complementarse con la evocación del solemne protocolo y de la atmósfera casi ritual con que se llevaba a cabo la concesión de una joya emblemática. Lo testifican unas interesantes cartas del embajador Felipe de Malla a su señor, el rey Fernando I de Aragón, fechadas en los primeros días de $1416^{32}$.

Con el propósito de restituir la unidad de la Iglesia occidental, en otoño de 1415 se reunieron en Perpiñán el rey de Aragón, el papa Benito XIII y el rey de Romanos, Segismundo de Luxemburgo. Fueron días de negociaciones en los que este debió presionar para que el Papa Luna abdicase y el rey Fernando le retirase su obediencia ${ }^{33}$. Poco después, Fernando comunica la decisión esperada a Segismundo, quien se halla en Avinón, enviándole a su embajador Felipe de Malla. Las cartas de este informando al rey de todo cuanto acontece en la ciudad papal descubren el intercambio de las respectivas divisas, seguramente apalabrado ya en Perpiñán. Malla cuenta que después de comunicar a Segismundo la voluntad del rey aragonés de conseguir la "santa unión", ante muestras de alegría por parte del primero, tuvo lugar la entrega del collar a Segismundo, quien lo recibió con sobirana alegria et acció de gràcias. Como signo

31 Esta combinación del balaje con las perlas - aunque en menor cantidad que en los fermalls de Alfonsose ve en algunos broches de Essen, en la Virgen de Altötting y en una estatuilla de Santa Catalina conservada en el Metropolitan Museum de Nueva York. E. KOVÁCS, op. cit., 2004, p. 256; Paris·1400, op. cit., 2004, pp. 176-177.

32 Fueron publicadas por F. DE BOFARULL, Felipe de Malla y el Concilio de Constanza, Gerona, 1882, pp. 1-22. Las comenta también F. VENDRELL, "Caballeros centroeuropeos en la corte aragonesa", Miscellanea Barcinonensia, XXVIII (1971), pp. 19-43.

33 F. SEBÖK, "Segimon i el viatge reial", Princeses de terres llunyanes. Catalunya i Hongria a l'edat mitjana, catálogo de la exposición, Barcelona, 2009, pp. 387-388. 
de gratitud y para magnificar tal donación, lo tench en son coll més de una hora et féu lo jurament dels capitols. Luego llegó el turno de Nicolás de Gara, conde Palatino de Hungría, y de otros caballeros -uno de ellos inglés- y escuderos, a los que Malla impuso el collar por voluntad del Emperador, dejando constancia en sus escritos del júbilo de los condecorados: et cert Senyor, molt apar bé, que vostra ampresa és noble, car la porten volenters, et la magnifiquen, et s'en tenen per honrats los qui la han. Imaginamos pues una celebración protocolaria, ritualizada, del juramento de los capítulos y de la imposición del collar, con galantes muestras de gratitud por un presente que honraba y dignificaba a los condecorados.

En la misma carta Malla desvela que la intención de Segismundo es enviar su empresa a Fernando, lo que se confirma rápidamente ${ }^{34}$. Aunque no se especifique, se trataba de la del Dragón, creada por Segismundo en $1408^{35}$, cuyo emblema era un broche con un dragón retorcido, coronado por una cruz en llamas y no un collar, tan propio de las órdenes curiales de la época. Destaquemos un detalle que reviste gran simbolismo. Dice Malla: volria lo jorn dels Reys fer vos offerta de part del emperador de la sua ampresa. Pensaba pues en una jornada especial, la de la Epifanía, en la que los Reyes Magos hicieron sus ofrendas al Salvador. Aunque al fin no fuera posible, porque Malla permaneció unos días más en Aviñón, la importancia de lucir las divisas reales en la fiesta de reyes no parece que fuera algo fortuito. Otra carta, del 10 de enero, relata que lo jorn dels Reys Segismundo se presentó en la catedral adornado con la empresa aragonesa, haciendo gala de la misma entre los caballeros: a tota persona ab la qual parlava feya sobirana festa de la dita ampresa, dien "frater meus Rex Aragonum et ego unum sumus". Segismundo expresó además el deseo de que Fernando luciera la suya este mismo día. Estamos pues ante unos presentes reales que se veían oportunos para conmemorar la Epifanía y con los que se sellaban importantes acuerdos y se estrechaban complicidades; la proclama del rey de Romanos no deja lugar a dudas.

Realmente después de confirmarse la sustracción de la obediencia al papa Luna y ratificada la posición del rey de Aragón es cuando Segismundo ordena a sus mensajeros llevar la empresa a Fernando y a dos de sus hijos: el príncipe Alfonso y Don Pedro, lo qual molt singularment ell ama, se dice en la carta. Luego, a instancias del rey de Aragón, deben continuar su misión para entregarla al rey de Castilla, Juan II. Resulta también significativo de la importancia que estos gestos tenían en el ambiente curial el hecho de que Malla se despida del rey aragonés notificándole que, en la

\footnotetext{
34 Una nueva carta, fechada el 1 de enero de 1416, descubre que Malla acaba de ser informado de que los mensajeros de Segismundo (moceen Miquel y micer Othobono) le acompañarán, de modo inminente, para entregar la empresa al rey de Aragón.

35 La carta de fundación es del 12 de diciembre de 1408. Los objetivos de Segismundo son similares a los de los fundadores de otras órdenes principescas: reafirmar su posición, recibir la ayuda necesaria para alcanzar sus objetivos políticos, asegurar la fidelidad de su círculo de adeptos para consolidar su reino y asegurar la sucesión al trono. La divisa del dragón revela que la orden pertenece a la serie de las que optaron por el patronazgo de San Jorge. P. LÖVEI, "Les ordres de chevalerie princiers au Moyen Age, en particulier l'ordre du Dragon de Sigismond", Sigismundus rex et imperator. Art et culture à l'époque de Sigismond de Luxembourg, catálogo de la exposición, Budapest-Luxemburgo, 2006, pp. 251-263.
} 
procesión realizada en la corte papal, tanto Segismundo como sus caballeros han ostentado la empresa de las jarras y el grifo.

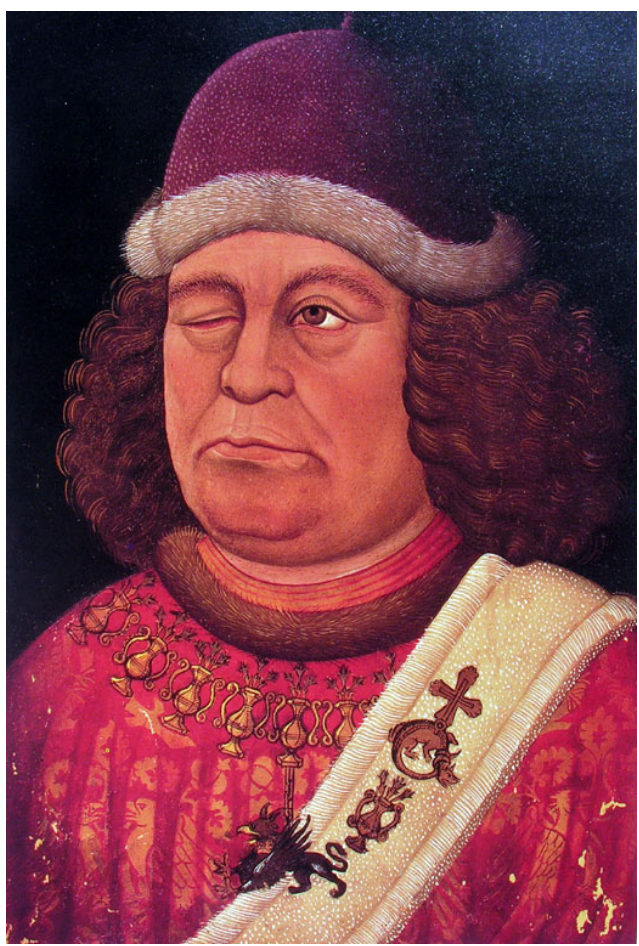

Fig. 4. Retrato del poeta Oswald von Wolkenstein en su Liederhandschriff B, c. 1432. Innsbruck, Universitätsbibliothek.

Es posible que uno de los condecorados fuera precisamente el poeta áulico Oswald von Wolkenstein del que se conserva un retrato en el frontispicio del llamado Liederhandschriff $B$, fechado hacia 1432 (Fig. 4). Puesto que perteneció a la comitiva de Segismundo, no es de extrañar que recibiera importantes divisas, como pone en evidencia el retrato. Luce un soberbio collar de jarras, con un gran grifo como colgante que resalta sobre la estola blanca, el otro distintivo de la orden fernandina. Subrayando su pertenencia a esta sociedad, en la estola lleva otra jarra de lirios como broche que se combina, proclamando la alianza de empresas, con la insignia del dragón rematado por la $\mathrm{cruz}^{36}$.

36 Una combinación similar de divisas - sin el collar- se ve en otras representaciones de caballeros, como la de G.F. Capodilista, y en varias lápidas sepulcrales, adoptando formas diversas. A título de ejemplo, mencionemos las de los hermanos Étienne y Jean de Perény, fallecidos en 1437 y 1458 . No es de extrañar tal proliferación, pues Segismundo había sido autorizado por Fernando de Aragón a conceder la orden de la jarra y el grifo a 50 miembros que él considerara merecedores de tal distinción. Sigismundus, op. cit., 2006, pp. 343-354. 
Fernando I moría en 1416 y Alfonso, en tanto que primogénito, se convertía en el maestre de la orden. Así lo había dispuesto sin ambigüedades su padre al fundar la orden, decretando que Alfonso - $\mathrm{u}$ otro sucesor de esta primogenitura - en virtud de la preeminencia que ello suponía, mantuviese en toda su vida "la dicha mi devisa con las Reglas e condiçiones que adelante se siguen”. Si en su niñez Alfonso había recibido de su padre la divisa, al subir al trono de Aragón con tan solo veinte años, pasaba a ser el depositario de todos los derechos de la orden paterna, con la consiguiente facultad de escoger a los caballeros que podían pertenecer a la orden y ser portadores de sus emblemas. Sin embargo las arcas reales no siempre debían de permitir dispendios suntuarios para magníficos collares como los que se han evocado. No es de extrañar, pues, que Alfonso proceda a desmembrar sus alhajas para atender compromisos de todo tipo y poder ofrecer al menos jarritas-broche, como vimos al mencionar el primer collar de su inventario.

Es imposible rastrear la historia de la orden en tiempos de Alfonso y las repercusiones iconográficas que tuvo en las obras que el nuevo rey mandó realizar. Aunque las joyas de la etapa napolitana del Magnánimo (1442-1458) también se perdieran, quedan suficientes representaciones de las jarras que constatan la afección de Alfonso por la empresa paterna ${ }^{37}$. En el contexto monumental del Castel Nuovo, el emblema de la jarra de lirios aparece camuflado entre la decoración flamígera de la ménsula que soporta el balcón principal. En el arco triunfal que da acceso al castillo, la victoria alada de la izquierda lleva no solo la prescriptiva corona de laurel para ofrecerla al triunfador, sino también la emblemática jarra de lirios. Y en la representación de la entrada triunfal de Alfonso en la ciudad, con todo su cortejo, que fue inmortalizada también en el arco, se le ve luciendo precisamente el collar de la orden ${ }^{38}$ (Fig. 5). Los grifos rampantes que flanquean y sujetan las armas de Aragón podrían también tener un sentido emblemático. Aunque en el encargo de azulejos que se hizo a un alfarero valenciano para las dependencias del castillo no se mencione esta divisa, se han conservado piezas cerámicas que muestran cómo la jarra también decoró algún pavimento real. Y en las techumbres y manuscritos tampoco falta el emblema fernandino.

Por razones políticas, diplomáticas o personales Alfonso procedió a la concesión del collar a miembros de diversos niveles sociales; premió la devoción de personas que formaban parte de la corte regia y honró a aquellos que la frecuentaban ocasionalmente ${ }^{39}$. No es de extrañar, por tanto, que la realización de collares de la orden - o simplemente de pequeñas jarras sueltas- quede bien refrendada en los pagos de la tesorería real, sobre todo en los últimos años de vida de Alfonso ${ }^{40}$.

37 J. DOMENGE, op. cit., 2010, p. 324.

38 G. VITALE, op. cit., 1999, pp. 46 y 49; F. RUIZ QUESADA, "Els primers Trastàmares. La legitimació mariana d'un llinatge", M.R. TERES (coord.), op. cit., 2011, pp. 87-88.

39 G. VITALE, op. cit., 1999, pp. 46-48.

40 Disponemos únicamente de las noticias que publicara C. MINIERI RICCIO, op. cit., 1881, passim. De conservarse los documentos originales tal vez se podrían conocer detalles sobre la forma, materiales y ornamentos de estos joyeles. 


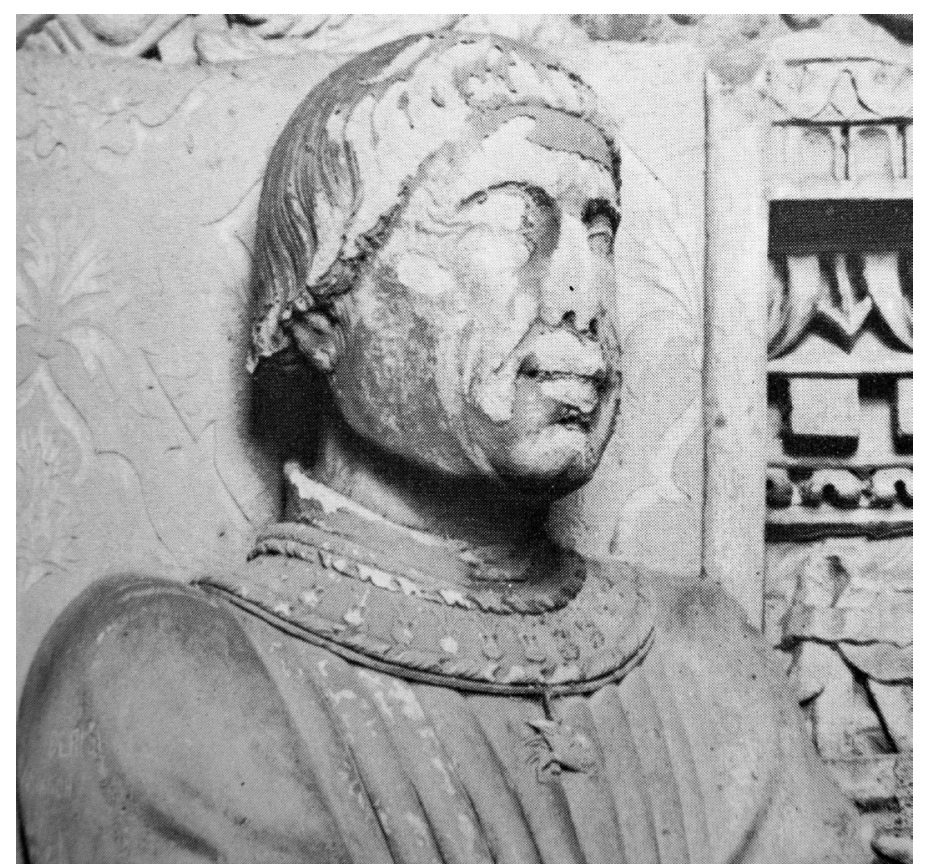

Fig. 5. Alfonso el Magnánimo con el collar de las jarras y el grifo. Representación de su ingreso triunfal en Nápoles. Arco de Castel Nuovo.

En 1442 el orfebre Paolo de Roma fabricó cinco jarras de la empresa de la estola y en 1451 el artífice Francesco d'Antignano di Capua recibió 160 ducados por un collar de oro colle giarrette. Un orfebre de probable origen italiano que estuvo largo tiempo al servicio del rey tuvo un destacado rol en la elaboración de estas manufacturas. Guido d'Antonio percibió en 1451 la considerable cifra de 1.500 ducados por ocho collares de oro con las jarras; uno era para el propio rey y otro para su hijo Fernando. Cuatro años después Guido continuaba recibiendo encargos de orfebrería, entre los que sobresalen cinco collares emblemáticos, de oro o plata ${ }^{41}$. De estos pagos parece deducirse que habitualmente se seguía un modelo compuesto por treinta jarras. El mismo artífice realizó 100 jarritas de plata dorada y otras 126 de plata blanca, que podrían tener relación con los bordados de cuatro jubones para dos pajes del rey. Y en el mismo periodo está documentada la actividad de Álvaro de Salamanca, maestro encargado de fabricar las estolas de la orden de Nuestra Señora, lo que permite suponer que algunos collares se entregaron conjuntamente con el que fuera el otro dis-

41 Uno de plata blanca para su paje Giovanni Battista; otro de oro para su camarlengo Marino Curiale; un tercero -ya mencionado- con 30 jarras y 30 nudos de oro para el paje Simonetto de Settimo; el cuarto -que combinaba jarras y troncos- era para Fray Lluís Puig, maestre de la orden de Montesa y, por último, un quinto ejemplar de plata entregado a Ferrante de Vares, gentilhombre de la guardia del rey de Castilla. Para una relación de los encargos que hizo el Magnánimo a Guido d'Antoni a partir de 1424, cfr. J. SANCHIS SIVERA, op. cit., 1924, pp. 44-48. 
tintivo de la orden, la estola blanca, como hemos visto en el caso del poeta húngaro y en el retrato de Heinrich Blarer. Al año siguiente (1456) el rey ofreció el collar con el grifo -esta vez con las alas esmaltadas de blanco ${ }^{42}$ - al caballero inglés Giovanni Import, establecido en su corte. Y poco antes de fallecer el rey lo recibía Bernabé Adorno (1457).

Son dignas de mención otras cuatro concesiones de la divisa al más alto nivel, aunque no queden reflejadas en los registros de la tesorería. En 1445 el duque de Borgoña, Felipe el Bueno, quiso condecorar a Alfonso con la orden del toisón de oro. Según Zurita, Alfonso recibió la divisa con mucha solemnidad, pero no sin condiciones, pues políticamente no podía aceptar todos los requisitos que las reglas de la orden imponían; recíprocamente Alfonso envió al duque la suya, con las mismas condiciones.

En 1452 salió de Nápoles con la empresa alfonsina el emperador Federico III, casado con Leonor de Portugal, sobrina de Alfonso. Con ironía y sarcasmo en la curia romana se comentó que Federico andò a Napoli imperatore, et è tornato cavaliero di banda -o sea, de la Estola-, según narra Vespasiano da Bisticci en la Vita de Alfonso de Aragón. Ciertamente, el gesto de Alfonso se vería con inferioridad respecto a la propia dignidad imperial de Federico ${ }^{43}$. Sin embargo, ya hemos mencionado que el emperador fue retratado con el collar de las jarras y el grifo, luciendo con orgullo tal condecoración (Fig. 6).

En la festividad de San Jorge del siguiente año, 1453, se efectuó un intercambio de divisas entre los reyes e infantes de Castilla y Alfonso de Aragón. Juan II, su esposa Isabel de Portugal, los infantes Alfonso e Isabel y doce caballeros del rey recibieron el collar de las jarras aragonesas. En reciprocidad, Alfonso el Magnánimo y doce miembros de su casa tomaron "el collar de la Escama con la devisa de la Banda del rey de Castilla". Como ha sido subrayado ${ }^{44}$, algunos detalles de este evento son significativos: su celebración el día de San Jorge, patrón de la caballería; la concesión de la empresa a doce caballeros, a imagen de los doce apóstoles, y la integración de aristócratas e infantes. Después de dos décadas de enfrentamientos entre las dos coronas, se sellaba una paz con un gesto en el que se amalgaman elementos caballerescos, religiosos y dinásticos.

Tan solo un año antes de fallecer Alfonso, su sobrino Carlos de Viana, infante de Aragón y de Navarra, le visitó en Nápoles (1457) para solicitar apoyos y alianzas. Una carta dirigida a la reina María cuenta el "honor" que Alfonso hizo a Carlos al desprenderse de su propio collar de las jarras para ponerlo en el cuello de su invitado, junto con la estola. Era un ejemplar altamente lujoso, pues entre las garras del grifo había un gran diamante. No es de extrañar que entre los bienes que se inventariaron a la muerte de Carlos (1461) se encuentre en lugar destacado el collar de la empresa fernandina ${ }^{45}$.

42 La presencia del esmalte blanco no concuerda con lo que se establecía en los estatutos de la orden. En estos se contempla el plateado y dorado de las alas del grifo, según las victorias militares del condecorado.

43 G. VITALE, op. cit., 1999, pp. 39-40 y 43.

44 A. FERNÁNDEZ DE CÓRDOVA, op. cit., 2012, p. 36.

45 M. NARBONA, “;Ay!... las divisas de Carlos de Évreux, Príncipe de Viana (1421-1461)”, Príncipe de Viana, LXXII, 253 (2011), p. 372. En un retrato del Carlos que se conserva en la Biblioteca Nacional de 


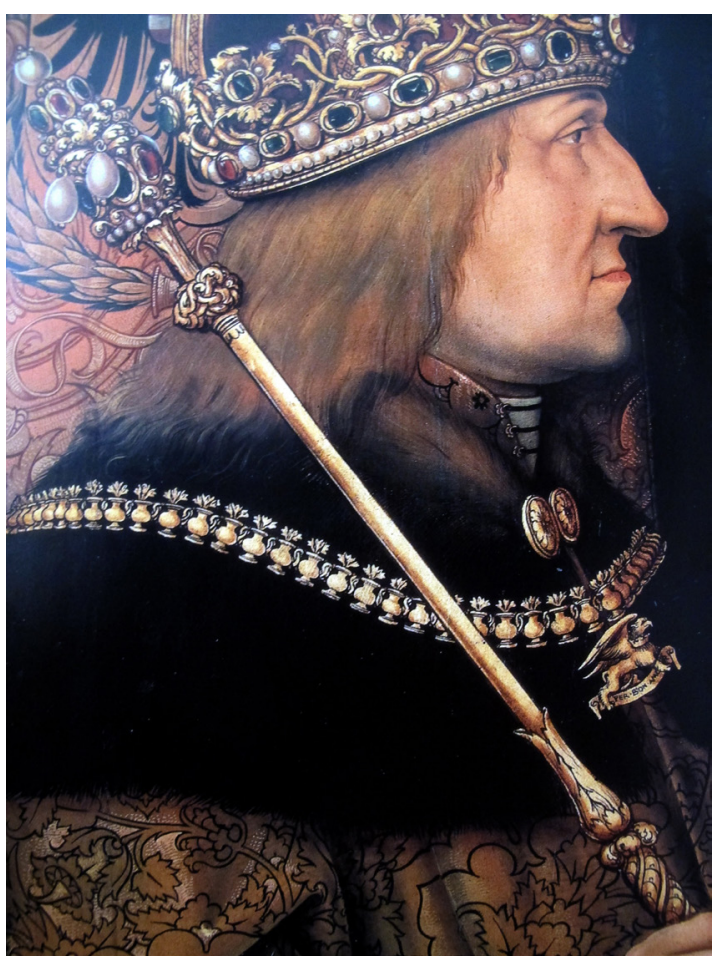

Fig. 6. Retrato del emperador Federico III. Viena, Kunsthistorisches Museum, inv. n. 4398.

Como bien revela G. Vitale, la historia de esta orden, así como los valores político y diplomático de la "vieja" divisa Trastámara, no perecen con la muerte de Alfonso ni tampoco con la creación de la nueva orden del armiño, por parte de su hijo Fernando I de Nápoles, en 1465. Los encargos de collares y estolas se prolongan durante el reinado de Fernando y también en el de su sucesor, Alfonso II. Al parecer este asoció la concesión de la divisa de la jarra con la del armiño para subrayar la pertenencia de la dinastía napolitana a la historia y tradición de la casa Trastámara. En la iglesia napolitana de Santa Anna dei Lombardi, la escultura yacente de Antonio d'Alessandro - que lleva la estola decorada con una gran jarra- y el frontal de su sepulcro - con dos jarras de lirios- atestiguan la vigencia de esta divisa ${ }^{46}$. A su vez ponen de manifiesto que la forma de representarla evolucionaba al compás del tiempo: el escultor Tomasso Malvito, inmerso en la cultura clasicista de la ciudad partenopea, al finalizar la centuria (1491) brinda esta novedosa representación de la divisa, aunque su significado permaneciera inalterado.

\footnotetext{
Madrid se le ha representado con un gran collar de pedrería -sin aparente sentido emblemático- del que cuelga la divisa del grifo.

46 G. VITALE, op. cit., 1999, pp. 40-43 y 50-51.
} 